\title{
DIRECT EVANGELISM IN INDIA
}

The direct central drive of my evangelistic work among educated classes throughout India has been the Hindu, the Moslem being touched more or less incidentally. However, in all the audiences I have addressed there have been quite a few Moslems, and in the aftermeeting for questions the meeting has often taken a Moslem turn. I have even had prominent Mohammedans sign the notices that have gone out for the meetings as if they were calling the meetings, though they knew that I would make a frank open Christian appeal. And in most places we have at least one Mohammedan as chairman of the meetings in a series. And in the quiet talks between meetings I have sat face to face with many an earnest Moslem enquirer. I do not write as an expert on evangelism among Moslems, but as one who has touched it only while holding another objective. While this is true, I have felt that there are advantages in dealing with the Moslem in an atmosphere not his own. In a general meeting where one is making an appeal for personal, social and national regeneration the Moslem is lifted out of the petty controversy of texts and books, and the big things of life face him. He is therefore more reachable in that atmosphere than in his own.

I believe that there are tremendous possibilities for direct evangelism among Moslems in India, and they are being augmented by present tendencies.

I. There is a great revival of Mohammedanism in India taking place at the present time, but it has the elements of a kick-back in it. Before the war in the clash of ideas in India the Moslem, pushed by Christian ideals, felt called on to spiritualize away some of the grossness of 
his own conceptions. Jihad was not a using of literal swords, but it meant a war against evil in the abstract, just as we call Christians to war. But an in rush of the old Mohammedan spirit has taken place since the war, and the old teaching stands out in its bare nakedness. In a recent court case for the trial of some Moslem fanatics, who had murdered a British official from sheer Jihad frenzy, the lawyer defending them pleaded that in murdering the Kafir they had followed the dictates of their own conscience and the precepts of their own religion, and could not therefore be punished. This is typical of the bare literalness that has swept over Moslem thinking in recent months. But in the soberer moments that are to come, this revival will be a source of embarrassment to the open-minded Moslem.

2. The Moslem has no reserve trenches as the Hindu. You may beat the Hindu from one intellectual position, and he seems to have an indefinite number of reserve trenches into which he can retreat. $\mathrm{He}$ can be almost a Christian and still be a Hindu, so elastic is his position.

But not so with the Mohammedan. $\mathrm{He}$ is one or the other, either rigidly against you, or, if you can succeed in beating him from that position, there is nothing left but to be for you. I have been surprised to find men who were absolutely opposed suddenly collapse in their opposition and be for you. The secret is that they had no reserve positions. And the point is that the present tendency to cast aside any attempt at philosophical reasonableness and go in for bare, naked Koranic literalness for the future moral, religious, social and political programme is a position that brings present revival, but future collapse. The whole tendency of the best elements in world life is against the position they are taking up. The fort of the Kuran into which they retreat for their whole life stand may prove a strength for awhile, but a fort is a dangerous place of ultimate refuge.

3. The weight of modern conditions is going to be on Hinduism and Mohammedanism in the future as India is 
given self-government. Hitherto the weight of things has been on the British Government, and these religions have sheltered up under them. Theirs has been a protected position. Now the weight of modern conditions will come straight on these religions. I believe it will smash them. They are not built for a democratic future. Lecky says, "There is only one example of a religion not subverted by its contact with modern civilization, and that one example is Christianity." It can live in a progressive, scientific age. Now progressive world currents will sweep through the Moslem world, and it will find its inherent weaknesses.

To illustrate: An earnest Moslem college student came to see me personally after the close of one of my addresses. He said, "Don't you think that Mohammedanism is also democratic?" "Yes," I replied, "very democratic toward Moslems. But does your democracy extend to man as man, or man as Mohammedan? What is its attitude toward the non-Mohammedan, is it democratic there?" He replied that he was "afraid it was not." Then he said, "Don't you think we could change it?" "Yes," I said, "You could, but when you got through it would not be Mohammedanism." Then he replied, "I have been thinking about this matter for a long time. Could we not put together Mohammedanism and Christianity and make them one?" I asked him how he would do it. He replied, "Christ lived a very high, noble, holy life, and He never married. Now Mohammed did marry, so I would suggest that we make Christ the theory of religion and Mohammed the practice." A splendid compliment! And one could scarcely get a more vivid contrast between the two religions: One stands for a call out of the lower into the higher, the ought-to-be standing over against the is, and asking it and helping it to come up higher, even to Christ; the other religionizes the lower is, and asks it to stay where it is, even at Mohammed. But the world is under the call of a higher, and cannot stay.

4. The Hindu and Mohanmedan are just now violent- 
ly attached, and united against the British. But it is a unity of a common object of hate. Herod and Pilate agree together. But the aims are divergent, one is national and the other is religious. The Moslem is agitating for the Khalifate, and the Hindu for self-government. When once the latter is given, the aims fall apart. The overmastering desire of each comes out, and they do not coincide. The Moslem is becoming violently attached to Turkey, the Hindu is for India. The Moslem is storing up a reaction from the side of the Hindus which is sure to come. That, too, will make his position in India more difficult.

5. But the greatest possibility for direct evangelistic work comes from the spiritual hunger brought on by this upset. If the above which I have written seems militant and outward, yet my method is otherwise. I do not attack them. When addressing them I present Christ openly, frankly, leaving them to draw conclusions of their own. And when one unfolds Christ, interpreted through Christian experience, it pulls upon the heart and conscience. This upheaval is creating a desire for a positive dynamic faith. With a constructive message at this time our opportunity is supreme. For when the facts of life are faced, there is no other way out except the Christ way. In an aftermeeting recently, when I asked those who would accept Christ to stay, among the forty who stayed there were about a dozen Moslem students. They were students who had been in the midst of the noncooperation movement with its intense excitement and bitter animosities, and yet here they were listening intently while I told them how to live this new life in Christ. Spiritual hunger was mastering them. In this moral and spiritual hunger created by these new conditions lies our opportunity. To get close to them with sympathy, courage and straightforwardness and present Christ interpreted through experience is our present task.

E. STanley JONEs.

India. 